\title{
2 \\ WHY WAS 5 RAR STATIONED AT NUI DAT?
}

\author{
David Horner
}

Phuoc Tuy Province and Nui Dat are two names that resonate strongly with Australian Vietnam veterans. More Australian soldiers served in Phuoc Tuy than in any other part of Vietnam and, while operating in the province and sometimes in nearby provinces, they were based at Nui Dat in the centre of the province. Certainly, members of the Australian Army Training Team Vietnam (AATTV) served throughout South Vietnam, and the 1st Battalion, the Royal Australian Regiment (RAR), was based at Bien Hoa in the province of the same name in 1965-66. But from 1966 to their withdrawal at the end of 1971, 15 Australian infantry battalions, along with supporting arms and services, served in Phuoc Tuy. The Australian Logistic Support Group and the helicopters of No 9 Squadron RAAF (Royal Australian Air Force), based at nearby Vung Tau, were not located within the province, but elements were deployed to Nui Dat, and the helicopters operated throughout the province.

So why was Phuoc Tuy selected as the focus of Australian operations, why was the 1st Australian Task Force (1 ATF) based at Nui Dat, and who was responsible for locating it in the province? The answer to the last question is clear - it was the chief of the general staff (CGS), Lieutenant General Sir John Wilton. But what were the factors behind Wilton's decision? This chapter seeks to answer these questions. It also examines why Australia sent a two-battalion, rather than a more balanced three-battalion, task force to Vietnam in 1966. 


\section{General Wilton}

Appointed CGS in January 1963 at the age of 52, Wilton had extensive command, operational and staff experience. ${ }^{1}$ After graduating from the Royal Military College (RMC) in 1930, he served in the British artillery in India before joining the Indian Mountain Artillery in Burma. By May 1939 he was back in Australia, serving in the coast artillery until May 1940 when he joined the Australian Imperial Force. He was brigade major of the 7th Division Artillery in the Syrian campaign in 1941 and attended the Middle East Staff School. From August 1942 to August 1943 he was chief operations staff officer of the 3rd Division in the advance towards Salamaua in New Guinea. He then joined the Australian Military Mission in Washington DC, before returning to operations in May 1945 as a key member of General Sir Thomas Blamey's headquarters on Morotai and, for a while, in Manila.

After the war, Wilton moved to Army Headquarters (AHQ) Melbourne, and by 1947 was director of military operations and plans (DMO\&P). In July 1950 he visited Malaya as part of a mission reporting on the British Commonwealth campaign against communist terrorists in that country. He attended the Imperial Defence College, London, in 1952 and then took command of the 28th Commonwealth Brigade in Korea. Part of the 1st Commonwealth Division, the brigade consisted of two Australian and two British battalions. It occupied a key defensive area, covering Seoul, along the battle-line that stretched across the Korean peninsula.

By November 1955 Wilton was brigadier, general staff at AHQ, concentrating on the defence of South-East Asia, including issues surrounding the Malayan Emergency, Vietnam and the South-East Asia Treaty Organization (SEATO). Promoted to major general in March 1957, he was commandant of the RMC until June 1960, when he became chief of the Military Planning Office in SEATO headquarters, Bangkok. There he dealt with the alliance's strategic problems in the region, especially the conflicts in Laos and Vietnam. From that position he was appointed CGS.

1 For Wilton's career, see David Horner, Strategic command: General Sir John Wilton and Australia's Asian wars, Oxford University Press, Melbourne, 2005. 
Wilton was well suited for his task as the government's principal military adviser. Reserved, self-disciplined and tactful, he easily won the confidence of ministers. He had a vision for the services and he had clear and considered ideas about the importance of alliances in the defence of Australia. Above all, he was a man of strong character; he believed in what he was doing and could not be seduced by personal ambition. He seemed less suited for command in the field. Nonetheless, he had much command experience, having had continuous regimental postings for the first decade of his service, and he had performed well as a brigade commander in Korea. But he did not reveal an engaging personality when dealing with soldiers or more junior officers. Known as 'Smiling Jack' and later as 'Sir Jovial', he was renowned for his lack of small talk. Soldiers would follow him because they had confidence in his judgement and knew that he cared for their welfare, not because of his charisma.

Few heads of the army have faced such a range of challenges as Wilton did in his three-year tenure as CGS. A major concern was the deteriorating strategic situation in South-East Asia. Indonesia began its confrontation of the new state of Malaysia in 1963, and sent 'volunteers' to fight in Sabah, Sarawak and even mainland Malaysia. Australian troops were based in Malaysia and the government deployed army engineers to Sabah. The AATTV had been sent to Vietnam in 1962 and in 1964 the government approved the employment of team members as advisers in the field.

As the pressure for more deployments mounted, Wilton advised the government that the army was too small to meet the commitments. Eventually, in November 1964, the government announced a huge expansion of the army, to be achieved by the introduction of a selective national service scheme. The increased manpower was matched by the purchase of new weapons and equipment, and the construction of additional accommodation. Wilton changed the army from the Pentropic organisation, with five large battalions per division, and no brigade structure, to a 'Tropical' organisation, with a division consisting of nine smaller infantry battalions and intermediate task force headquarters. This, and the national service scheme, allowed the army to grow from four battalions in 1964 to nine in 1967. In March 1965, 3 RAR and a Special Air Service (SAS) squadron were sent to Borneo, and in June 19651 RAR arrived in South Vietnam. 
Wilton did not shy away from these operational commitments. Indeed, he believed that, provided that the Australian Government was clear about its purpose, a combat commitment to Vietnam was necessary. But based on his past experience, he was determined to ensure that 1 RAR was not exposed to suffering unnecessary casualties.

\section{RAR's role}

To understand why 1 ATF was deployed to Phuoc Tuy in May/June 1966, it is necessary to understand how 1 RAR was employed in the previous year. When the Cabinet approved the deployment of 1 RAR in April 1965, Wilton advised Sir Edwin Hicks, Secretary of the Department of Defence, that as the Australian battalion would operate as part of a US force, it required a compatible role; in no circumstances could it be given 'responsibility for a separate area as it is not large enough nor is it organised to handle such a situation'. ${ }^{2}$ On 20 April the Defence Committee discussed Wilton's concerns. ${ }^{3}$ During the meeting Sir James Plimsoll, Secretary of External Affairs, questioned Wilton closely, and stated that:

Australian troops should not be used on their own in exposed positions. If Australia's only battalion in Vietnam was completely lost, our presence there would be gone, quite apart from other considerations. The expression of this to the Americans would need to be handled carefully, and we must avoid any suggestion of mollycoddling our forces, but something could be said orally between the relevant Commanders. ${ }^{4}$

On the following weekend, Wilton reviewed the plans with Brigadier Ken Mackay, the DMO\&P at AHQ. Mackay was later to play a major role in the decision to base 1 ATF in Phuoc Tuy Province. The 48-year-old Mackay was a highly qualified officer. After graduating from the RMC in 1938 he had served in both artillery and infantry appointments in the Second World War. He had valuable experience in joint staff positions.

2 Letter, Wilton to Hicks, 15 April 1965, CCOSC (Chairman of the Chiefs of Staff Committee) files, box 16, file 513 .

3 Defence Committee Minute, 20 April 1965, CCOSC files, box 16, file 513. Chaired by the Defence Secretary, the Defence Committee included the Chairman of the Chiefs of Staff Committee (COSC), the service chiefs and the permanent heads of External Affairs, Treasury and the Prime Minister's Department.

4 Note for File re: Defence Committee minute 21/1965, M, 22 April 1965, NAA (National Archives of Australia): A1838, TS 696/8/4 pt 8. 
Towards the end of the Second World War he served in the small secretariat responsible for providing up-to-date briefings to the chief of the imperial general staff, Field Marshal Brooke in London. He was joint secretary of the Joint Chiefs of Staff in Australia during the establishment of the British Commonwealth Occupation Force in Japan and served at Australia House in London during the 1956 Suez Crisis.

Wilton directed Mackay to begin planning to send a full battalion group, including a battery of artillery and a troop of engineers, to Vietnam. It was the first step in building the force beyond the initial battalion. ${ }^{5}$ Although the government had decided to send a battalion it had still not formally committed it, and the army's planning was kept secret until the evening of 29 April 1965, when prime minister Robert Menzies announced in parliament that 1 RAR would be deployed to Vietnam.

Three days later, Mackay and a small planning team arrived in Saigon where General William Westmoreland, commander of US Military Assistance Command, Vietnam (US MACV), welcomed them. They learned that the Americans planned for 1 RAR to become the third battalion in the 173rd Airborne Brigade that was to defend the Bien Hoa airbase, near Saigon. They discussed 1 RAR's proposed roles and conducted a reconnaissance of Bien Hoa and Vung Tau, which would be the entry point for the battalion. At Wilton's direction, Mackay examined the US 173rd Brigade and satisfied himself that 1 RAR would be joining a first-rate organisation. By then the commander of the AATTV, Colonel David Jackson, had been appointed Commander, Australian Army Force Vietnam (AAFV), and together they agreed on a Military Working Arrangement with the Americans that Mackay signed on 5 May. $^{6}$

Returning to Canberra, on 13 May Mackay accompanied Wilton to the Defence Committee, which endorsed his report, approved draft directives for the Commander AAFV and the battalion commander, and approved the command arrangement whereby Westmoreland, not the South Vietnamese, would exercise operational control over the Australians. ${ }^{7}$ Wilton and Mackay also attended the meeting of the Foreign Affairs and Defence Committee of Cabinet on 18 May that approved the Defence

5 Letter, AM Morris (External Affairs representative on Joint Planning Committee) to Jockel, 27 April 1965, NAA: A1838, TS 696/8/4 pt 8.

6 Report, Mackay to CGS, 'Report by the Leader of Planning Team Visit to Saigon', 11 May 1965, NAA: A1945, 248/4/114.

7 Defence Committee Minute, 13 May 1965, AWM (Australian War Memorial) 121, 161/A/4. 
Committee's report. ${ }^{8}$ Mackay recalled that he and Wilton came under intense questioning about the security of 1 RAR's position at Bien Hoa. Menzies even asked about 'adequate fields of fire'. '

With 1 RAR preparing for operations at Bien Hoa, it was time for Wilton to check that all was in order there. He arrived in Saigon on 22 June determined to ensure there would be no problems integrating 1 RAR into an American brigade. He had clear views of his own on this issue, but before leaving Canberra, his deputy, Major General Frank Hassett, had reminded him of the pressures he (Hassett) had borne in Korea when commanding the lone Australian battalion there in $1951 .{ }^{10}$ Wilton would have been less concerned if it had been an Australian brigade in a US division, but a battalion was a relatively small command and he did not want the brigade commander thinking he could 'treat an Australian battalion in the same way as he can an American battalion'. He told Westmoreland and the brigade commander that 'we wouldn't agree to it', and as tactfully as possible said he disapproved of the way some US brigade commanders had acted in Korea. This was, he recalled:

a delicate situation; I received assurances all round that this wouldn't happen, but that the battalion commander would be brought in and consulted in planning arrangements for the employment of his battalion, they wouldn't just be committed at five minutes notice to a badly organised and planned operation. So with that sort of 'preparation', shall we say, things went off smoothly because they said: 'Look we'll just get the task agreed upon and let them do it in their own way'. I said: 'That's fine, you won't be disappointed'. ${ }^{11}$

Having resolved these command concerns, Wilton departed for Australia, leaving Colonel Jackson to ensure the directives concerning the security of the Australians were followed and 1 RAR's operations conformed to its agreed role.

8 Cabinet Minute, Decision No 975 (Foreign Affairs and Defence), 18 May 1965, NAA: A1945/43, 248/4/116.

9 Interview, K Mackay with author, 7 April 1986; letter, McMahon to Paltridge, 23 June 1965, NAA: A1945/39, 248/4/19.

10 Interview, FG Hassett with author, 14 March 2003.

11 Army Historical Programme, interview with Gen Sir John Wilton, 9, 13, 14 September 1976, p 12, AWM 107 (hereafter: Wilton interview). 
Wilton had been back in Canberra less than two weeks before there was an apparent attempt to change 1 RAR's role. On 4 July Jackson informed him that Westmoreland planned to form a general reserve based on the 173rd Brigade that could be deployed anywhere in Vietnam and he recommended the inclusion of 1 RAR. ${ }^{12}$ Wilton did not agree, explaining in a letter to the Minister for the Army, Jim Forbes, that 1 RAR's inclusion would involve it in 'a succession of hazardous operations which would inevitably result in heavy casualties'. ${ }^{13}$ Jackson (now promoted to brigadier) replied that Westmoreland wanted to conduct offensive operations, particularly in the II Corps Tactical Zone, and although 1 RAR was located in the III Corps Tactical Zone, he thought it should be permitted to take part, as the proposed operations would allow the Australians to 'have the greatest impact' on the war. Wilton was unmoved; he considered that Jackson would not be able to watch over Australian national interests effectively and there was the possibility of higher casualties. ${ }^{14}$

The restrictions on the use of 1 RAR were still in force when Wilton, accompanied by Major General Tom Daly, General Officer Commanding Eastern Command, visited Saigon for two days at the beginning of September on the way to a British Army conference in London. On the morning of 2 September, he called on Westmoreland who recorded in his diary that Wilton was apologetic that certain constraints had been placed by his government on the deployment of his troops.

I informed him that the last proposal that his forces could be used in operations contiguous to Bien Hoa was acceptable at this stage of the war. General Wilton suggested, and I heartily agreed, that we should try to solve these problems in military channels and try and keep them out of diplomatic channels, which serve only to complicate or confuse the situation. ${ }^{15}$

Next morning, Wilton signalled Hassett in Canberra that, after discussion with Westmoreland, he believed 1 RAR should be permitted to operate anywhere in the III Corps area. He directed Hassett to put this proposal through the Chairman of the Chiefs of Staff Committee (Air Chief Marshal Sir Frederick Scherger) to the Defence Minister, adding that

12 Signal, Jackson to Wilton, 4 July 1965, AWM 121, 161/A/4.

13 Letter, Wilton to Army Minister, 6 July 1965, AWM 121, 161/A/4, and NAA: A1945, 248/4/124.

14 Signal, Wilton to Jackson, 9 July 1965, AWM 121, 161/A/4.

15 Entry for 2 September 1965, Westmoreland Papers, History File No 2, US Center of Military History. 
1 RAR should now 'have a more active role. It is the best battalion in the theatre and its morale will suffer if it is not used to best effect in the mobile offensive role' ${ }^{16}$ Securing the extension to 1 RAR's area of operations took longer than Wilton had hoped, mainly because the Defence Minister, Shane Paltridge, had fallen ill, and because of the need to get agreement from the Minister for External Affairs. ${ }^{17}$ It was 1 October before Wilton signalled Jackson that 1 RAR was 'available for operations more distant from Bien Hoa'. ${ }^{18}$

The importance of this episode lies in what it reveals about the attitude of the Australian Government, and particularly of Wilton, who was determined to limit casualties and not expose Australian troops to capricious American operations. Wilton and the Australians had a different philosophy to the Americans, believing that the Americans favoured a direct approach, using plentiful firepower to kill as many enemy soldiers as possible. Such an approach might result occasionally in heavy allied casualties, and Australia could not afford to take the risk that its sole battalion might be the one that took the casualties. In any case, the Australians preferred a more methodical approach to counterrevolutionary warfare.

\section{Considerations on expanding the Australian force}

Wilton played the key role in planning to expand the force in Vietnam. Indeed, as soon as 1 RAR arrived in Vietnam, Wilton and his advisers began considering how the force could be built up to an independent task force, so the Australians could apply their own doctrine for counterrevolutionary warfare. At a meeting of the Chiefs of Staff Committee on 15 July, he argued that they should begin planning to build up the commitment to a task force of two infantry battalions with supporting elements, plus a detachment of RAAF Iroquois helicopters.

16 Signal, Wilton to Hassett, 3 September 1965, NAA: A1945/42, 248/4/128.

17 Signal, Mackay to Wilton, 13 September 1965, AWM 121, 161/A/5.

18 Ian McNeill, To Long Tan: The Australian Army and the Vietnam War 1950-1966, Allen \& Unwin, Sydney, 1993, p 121. 
Meanwhile, information arrived that the US Government might soon request Australia to increase its force contribution. Setting out how Australia might respond, Wilton explained to Scherger on 20 July:

The war in Vietnam is essentially an infantry war and the requirement for additional forces is basically for more infantry battalions. Other supporting arms such as artillery, APCs and engineers are important but have a less vital part to play in the present situation. ${ }^{19}$

He continued that 3 RAR had just completed a 'strenuous two-year tour in Malaya and Borneo and is due for relief and return to Australia'. It was to be relieved by 4 RAR, which was about to deploy to Malaysia. On return from Malaysia, 320 members of 3 RAR were to transfer to the embryonic 7 RAR to help form the new battalion. The only available battalions were 2 RAR, 5 RAR and 6 RAR; each had a strength of about 550 , but these included some 100 soldiers who were ineligible for service overseas because of under-age or medical classification reasons. The earliest these battalions would be ready for operations would be February 1966. If another infantry battalion were sent to Vietnam at short notice it would seriously disrupt and delay the national service program and should only be contemplated if it were 'a matter of dire operational necessity'. Wilton concluded:

I believe that we should plan now to build up our existing force to a Task Force of two infantry battalions plus the required scale of combat and logistic support units, together with a detachment of army light aircraft and a detachment of RAAF Iroquois utility helicopters. ${ }^{20}$

Noting this advice, on 29 July the Defence Committee recommended increasing the force by an artillery battery and an engineer troop in the short term, with another infantry battalion to be made ready by February or March 1966.

With these plans in mind, in early August Brigadier Mackay visited Saigon where Lieutenant General John Throckmorton, acting commander US MACV, and Throckmorton's chief of staff, Brigadier General William DePuy, told him that president Johnston was requesting additional

19 Letter, Wilton to Scherger, 20 July 1965, and attached paper, 'An assessment of the Army's ability to expand its force in Vietnam', AWM 121, 161/A/4.

20 Ibid. 
Australian forces, and asked what Australia had in mind. ${ }^{21}$ Johnston had approved the deployment of a further 125,000 troops to Vietnam, and the Republic of Korea was expected to dispatch a division. ${ }^{22}$ Anxious to reserve an area for an Australian task force, Mackay called on DePuy before he left to return home. As he recalled:

I said, you know, old Bill, 'Just put a ring around Phuoc Tuy Province. If we're going to come in with a force, this is the place I believe we ought to come in to ... Now flog off this other area, flog off this and that, do what you like, but don't let this one go.' He laughed and said: 'OK, we'll put a thumb mark on it for you'. ${ }^{23}$

This was just prudent planning. While Wilton wanted to expand the force to two battalions, he recognised such a force could not yet be sustained. But clearly the idea of a larger force was being discussed; for example, on 12 August Wilton advised the Defence Minister, Senator Shane Paltridge, that:

if it became necessary to provide forces in the field in addition to the proposed task force of 3,500 plus existing commitments in Malaysia and New Guinea, we would be very close to the stage when a defence emergency should be declared. ${ }^{24}$

On 17 August the Cabinet agreed to send an additional 350 troops to Vietnam, but directed that the army not undertake any further planning to deploy a task force. ${ }^{25}$ The additional 350 troops enabled the battalion to be reinforced with a battery of artillery and a troop of engineers to form a battalion group - the force first suggested by Wilton on 27 April.

The army ceased planning for a two-battalion task force for the remainder of the year. On 29 November, however, the US Secretary for Defense, Robert McNamara, told the Australian Ambassador in Saigon that a request for a second battalion would be made shortly. ${ }^{26}$ On 7 December Hicks advised the Acting Defence Minister, Alan Hulme, that:

21 Letter, Wilton to Forbes, 19 August 1965, AWM 121, 161/A/1.

22 Report, Mackay to Wilton, 9 August 1965, AWM 121, 161/A/4.

23 Army Historical Programme, interview with Maj Gen K Mackay, 8 March 1972, p 12, AWM 107 (hereafter: Mackay interview). McNeill, To Long Tan, pp 182-4.

24 Letter, Wilton to Hicks, 12 August 1965, AWM 121, 161/A/4.

25 Letter, Secretary, Department of Defence to CGS, 18 August 1965, AWM 121, 161/A/5.

26 Report by the Joint Planning Committee at a meeting on 7 February 1966, CCOSC files, box 16 , file 513 , pt 3 . 
if an additional Australian contribution in Vietnam is judged to be the most effective Australian contribution, then it would seem that nothing short of a task force of at least two battalions with appropriate supporting units (say a total of 3,500 men) would meet the requirement. ${ }^{27}$

In the preceding months General Westmoreland had been anticipating the deployment of an Australian task force. For example, on 12 August Brigadier Jackson reported to Wilton that Westmoreland had said he would 'be very pleased to know ... how the possibility of an Australian task force was progressing' ${ }^{28}$ While there is no record, it is likely Westmoreland discussed this issue with Wilton when he visited on 2 September. Jackson was present for their meeting. Jackson recalled later that in the three to four months preceding the arrival of the Task Force, Westmoreland sought his views as to where an Australian task force could be deployed:

I think the sort of thing I tried to get across to him was that Australian troops were trained for operations in jungle and mountain warfare. They were trained particularly in patrol type operations and I didn't think they would be really suitable in the [Mekong] Delta unless they were given considerable support, particularly equipment support, as we had not really examined this sort of fighting in flooded paddy fields and miles and miles of water, and very heavy rain, and dense population. ${ }^{29}$

Jackson also recalled that when he visited the US Marines near the demilitarised zone at the far north of South Vietnam, the Marine commander said he would be delighted to have an Australian force there. Another suggestion was to base the Australian Task Force at Bien Hoa airfield, but there was not sufficient room as the 173rd US Brigade was already based there. Phuoc Tuy Province was also mentioned because it was 'sufficiently close' to Saigon.

It was an area which had gone bad in recent years. The VC [Viet Cong] were pretty much in control of it and it was therefore a thorn in the side of the Saigon defence ... It was an area in which there were no other major forces deployed so we had the position where allied forces were needed there and there was really nobody else likely to be available to go there - at that stage any rate. ${ }^{30}$

27 Letter, Hicks to Acting Defence Minister, 7 December 1965, NAA: A1945/42, 248/4/138.

28 Signal, Jackson to Wilton, 12 August 1965, AWM 121, 161/A/4.

29 Army Historical Programme, interview with Brig OD Jackson, 9 March 1972, AWM 107 (hereafter: Jackson interview).

30 Jackson interview, $\mathrm{p} 45$. 
Brigadier Mackay visited Vietnam between 14 and 20 December 1965, but before he departed Australia he was specifically briefed 'not to give any indication that Australia would be prepared to supply additional units for service in Vietnam at this stage'. ${ }^{31}$ Nonetheless, during Mackay's visit Jackson received the 'first firm information' that the Australian effort might be increased to the task force level. ${ }^{32}$ Mackay recalled that he discussed possible areas with General Westmoreland:

I don't know which visit it was on, but I can remember he had a very good grasp of the situation. He wanted a spread of forces into areas where the VC had not been challenged, and it was important that he have the various provinces covered, particularly where the ARVN [Army of the Republic of Vietnam] just had no forces at all..$^{33}$

As Mackay indicated, he was not sure when he met Westmoreland. In fact, he visited Vietnam three times in 1965, in May, August and December, and on the latter two occasions Westmoreland was absent from Saigon. In December Mackay certainly had discussions with Westmoreland's deputy, as well as his chiefs of operations, plans and logistics. ${ }^{34}$

Mackay was clear about the alternatives being offered: the Phan Rang area in central South Vietnam, the Mekong Delta and Phuoc Tuy Province. Phan Rang was 'pretty easy to eliminate because it was too isolated, there wasn't much enemy activity up there, and you'd be open to all sort of criticism, not pulling your weight etc.'. The problems with the Delta have already been mentioned. According to Mackay, the Americans were 'very keen to have our forces in Phuoc Tuy'. Considering the geography of the province, he thought:

it would be relatively easy to put our force, small as it was, between say 100,000 people in Phuoc Tuy and the VC who were out in the bush ... if we with a national force could sit in the centre of things here we could play an important role in the liberation and defeat of the VC. ${ }^{35}$

31 Minute, Secretary, Department of Defence to Wilton, 16 December 1965, AWM 121, 161/A/5.

32 Jackson interview, $\mathrm{p} 42$.

33 Mackay interview, $\mathrm{p} 10$.

34 Report, Brigadier K Mackay, 'Report on visit to South Vietnam by DMO\&P', 27 December 1965, NAA: A1945/42, 248/4/138.

35 Mackay interview, pp 10-11. 


\section{Approving a two-battalion task force}

While Mackay was still in Saigon, on 18 December the Minister for External Affairs, Paul Hasluck, who was also visiting Saigon, cabled Canberra that the South Vietnamese prime minister, Nguyen Cao $\mathrm{Ky}$, had made 'almost a request' for additional army and air force assistance. ${ }^{36}$ The head of the Australian Defence staff in Washington, Major General Charles Long, followed this on 23 December with advice that Westmoreland had said he envisaged an ANZAC brigade with two Australian and one New Zealand battalions plus supporting arms and services, logistic support units and a SAS squadron. ${ }^{37}$ Moving quickly, on 4 January Hicks sent Hulme two papers - one prepared by Scherger in consultation with the military chiefs, the other by Hicks's staff - outlining the forces that could be sent to Vietnam. ${ }^{38}$ The Cabinet considered them on 5 January; although it took no decision, it permitted the Chiefs of Staff to prepare a formal proposal. ${ }^{39}$

The Joint Planning Committee, chaired by the Director of Joint Service Plans, Major General Mervyn Brogan (a later CGS), now prepared a detailed report on what forces could be made available for service in Vietnam. The committee stated that the ground war was 'essentially an infantry war with brigade-sized forces securing major bases throughout the country'. In view of later criticism that Australia should have provided a three-battalion task force, as this would have allowed two battalions to operate throughout Phuoc Tuy Province while the third protected the Nui Dat base, it should be noted that Australia was responding to a specific US request for a second battalion. Further, at this stage 4 RAR was still on operations in Borneo, and the committee considered that while Indonesia was 'unlikely to step up confrontation ... the possibility of limited war cannot be excluded'. Both 5 RAR and 6 RAR would be ready for operations by May/June 1966, but 3 RAR, which had returned from operations in Borneo, and 7 RAR, which had recently been formed, would not be ready until September 1966. In addition, 1 RAR was still in Vietnam and it, and 2 RAR, would not be ready for operations until October 1966. The final battalion, 8 RAR, which was being raised, would not be ready until

36 Peter Edwards, A Nation at war: Australian politics, society and diplomacy during the Vietnam War 1965-1975, Allen \& Unwin, Sydney, 1997, p 86.

37 Cable WA1666, Washington to Canberra, 23 December 1965, NAA: A1945/42, 248/4/138.

38 The papers are in NAA: A1945/42, 248/4/138 and 248/4/145.

39 Cabinet Minute, No 1467, Melbourne, 5 January 1966, NAA: A1845/42, 248/4/138. 
March 1967. Planning needed to be based on 'the possibility that the operations may have to be sustained for an indefinite period'. That is, at this stage only a two-battalion task force could be supported. There was no suggestion of sending tanks to Vietnam - such a proposal does not seem to have been even considered. ${ }^{40}$

The Defence Committee endorsed this report on 10 February $1966 .{ }^{41}$ Wilton was adamant that if further forces were requested for service in South Vietnam it would not be practical 'to meet such a request in a situation short of a defence emergency'. ${ }^{42}$ Air Chief Marshal Scherger noted that a brigade was 'the optimum unit which operates alone' in Vietnam. If Australia did not deploy 'one national force incorporating all Australian units in the theatre' it risked the loss of national identity, the loss of valuable experience, especially in command appointments, the 'repetition of the problems which General Monash had in World War I and General Blamey in World War II of getting national units together under national command', and 'subjection to tactical doctrine to which we may not subscribe'. A national force would preserve 'national identity', provide essential military experience particularly in command and, because it would use Australian tactical doctrine, provide a force that was militarily more effective. ${ }^{43}$

These issues went to the heart of the problem of a small country operating in a larger coalition and were brought home just a few days later when Jackson reported that the Americans planned to use 1 RAR in operations close to the Cambodian border. Jackson objected and 1 RAR was withdrawn. Wilton agreed with Jackson's action and advised Hicks that this was 'the first occasion on which it has been necessary for Brigadier Jackson to exercise his responsibility, laid down in his Directive for the safety and well-being of AAFV'. ${ }^{44}$

On 2 March the Cabinet considered the Defence Committee's report and approved the deployment of a task force of two infantry battalions, an SAS squadron, combat and logistic support units, and eight RAAF

40 Report by the Joint Planning Committee at a meeting on 7 February 1966, CCOSC files, box 16 , file 513 , pt 3 .

41 Minute by the Defence Committee at a meeting on Thursday, 10 February 1966, NAA: A1945/42, 248/4/145.

42 Letter, Wilton to Hicks, 3 February 1966, NAA: A1945/42, 248/4/145.

43 Paper, Sir Frederick Scherger, 'South Vietnam-Australian Military Assistance', 10 February 1966, CCOSC files, box 16, file 513, pt 3.

44 Letter, Wilton to Hicks, 18 February 1966, NAA: A1945/42, 248/4/145. 
Iroquois helicopters. The total contribution of about 4,500 would include national servicemen. ${ }^{45}$ Much of the initiative for expanding the force had come directly from Wilton, who saw sound military reasons for it. As he said later:

When we sent our first battalion up, it was the most we could do in terms of the size of the force. We'd always, I think, known in the backs of our minds that when our manpower and other resources permitted this would have to be increased. ${ }^{46}$

\section{Wilton selects Phuoc Tuy Province}

On 12 March, just four days after prime minister Harold Holt announced that the Task Force was going to be deployed, Wilton departed for Saigon for meetings with Westmoreland and the Chief of the Vietnamese Joint Chiefs of Staff, General Cao Van Vien. Wilton had prepared a brief, setting out what he hoped to achieve in Vietnam, and he forwarded this through Scherger to the Defence Minister for his concurrence. In preparing the brief Wilton had discussed his proposals with the new Minister for the Army, Malcolm Fraser, explaining the advantages of finding a separate 'piece of geography' for the Australian Task Force. ${ }^{47}$ Accompanying Wilton were Brigadier Bob Hay, shortly to take over from Mackay as DMO\&P, and Lieutenant Colonel Alan Stretton, from the Directorate of Staff Duties. Soon after departing from Sydney, Wilton called Hay and Stretton into the aircraft's private compartment usually reserved for offduty crew and, as Stretton recalled, 'set about planning the details of the Australian build-up in Vietnam. ${ }^{48}$

Accompanied by his advisers from Canberra, as well as Brigadier Jackson, in Saigon Wilton went straight to a meeting with Westmoreland. They agreed that, on all matters concerning the Australian forces, Westmoreland would deal directly with the Commander, Australia Force Vietnam (COMAFV), who would be an officer of major general rank. Mackay was shortly to be promoted to fill this position. Operational control of the 1st Australian Task Force (1 ATF) would be through the commanding general of II Field Force, who was co-located with the commander of

48 Alan Stretton, Soldier in a storm, Collins, Sydney, 1978, p 181. 
II Vietnamese Corps near Bien Hoa. 1 ATF would be located in Phuoc Tuy Province, while the Australian Logistic Support Group would be at nearby Vung Tau.

Subsequent discussions between their staffs established the roles for 1 ATF. First, it was to secure and dominate the assigned tactical area of responsibility in Phuoc Tuy Province. Second, it was to conduct operations related to the security of the highway linking Vung Tau and Saigon as required. Third, it was to conduct other operations in the province. Fourth, it was to conduct operations anywhere in the III Corps Tactical Zone and also to conduct operations anywhere in the adjacent province of Binh Tuy (in the II Corps Tactical Zone) as agreed between Westmoreland and COMAFV. Thus, Australia placed clear limits on the geographic extent of 1 ATF's operations.

The key decision was the allocation of Phuoc Tuy Province to 1 ATF. As we have seen, Mackay had already identified it and Wilton had probably discussed possibilities with Westmoreland when they had met in September. Wilton, Mackay and other staff at AHQ considered the requirements for an Australian operational area, which Mackay described later in a presentation to the CGS Exercise in 1971. These were that the operational area should have significant enemy activity so there need be 'no thought by any party that Australia was pulling less than its share'; the area should not be contiguous to the borders with Cambodia, Laos or the demilitarised zone; it should be a geographically distinct area which could be left largely to the Task Force and with which the Australian national effort could be readily identified; and it should offer reasonably secure access to shipping and overseas aircraft. ${ }^{49}$

Wilton recalled later that the choice was between Phuoc Tuy and Bien Hoa. Although for military reasons 1 ATF had to be under US operational control, he 'preferred not to be brigaded with an American position. I wanted to have as much independence within the force limitations as I could, so I could keep a closer eye on it'. He thought 'our two-battalion task force was worth any US three-battalion brigade', and that placing it in the province gave 'us the best opportunity to make the most impact nationally — which is always an important consideration in a war like this'. He wanted 'to get clear of the American densely populated

49 Maj Gen Mackay, Chief of the General Staffs Exercise 1971, Notes for Speaker - Maj Gen Mackay. Papers from the CGS Exercise in author's collection (hereafter: CGS Exercise 1971). 
area, and get into a place where they could operate, in a way we thought was most effective'. Another disadvantage in selecting Bien Hoa was that Australian resupply ships would have to sail right into Saigon where they might be delayed for some time. Phuoc Tuy could be resupplied through Vung Tau. ${ }^{50}$

But the most important reason concerned the safety of the force. Vung Tau was on a nearby and isolated peninsula, so 1 ATF could be evacuated or reinforced by Australian national resources should the situation in the province deteriorate. As Wilton explained, 'if the war went really bad and some frightful disaster was impending, we could look after ourselves'. Considering all these reasons, Wilton said: 'all right, we'll go to Phuoc Tuy Province'. ${ }^{51}$ Then, according to Stretton, they went through 'a facesaving exercise with the South Vietnamese', visiting various generals who each said that he had decided to allocate the province to the Australians. Stretton thought that in selecting the province "Wilton showed remarkable military judgement and that there would have been a greater loss of life if the Australian force had been allocated to any other province'. ${ }^{52}$

The decision to base the Australian Logistic Support Group at Vung Tau caused more problems. The only available site was a windswept sandy area east of the city, but the local mayor told Wilton and Jackson that a senior military officer in Saigon had to give his approval. So, they went back to Saigon and, as Wilton described it, he 'nailed this fellow down at a reception a couple of nights' before they left Saigon. Wilton said, 'Now look, this is the place we want. Can you give me your assurance that this will now be allocated without delay?' 'Oh yes', replied the general, 'that will be done'. Wilton accepted this assurance but reminded the general that if the area was not made available 'we can't bring in our force'..$^{53}$ As it happened, Jackson secured final approval when the first ship carrying supplies was only a week from Vung Tau, and only after he threatened to have the ship turned around. ${ }^{54}$

50 CGS Exercise 1971.

51 Wilton interview, p 21.

52 Stretton, Soldier in a storm, pp 182-3.

53 Wilton interview, p 24.

54 Jackson interview, p 48. 


\section{Why Nui Dat?}

Wilton's decision to locate 1 ATF in Phuoc Tuy Province has not been seriously questioned, but the decision to base 1 ATF specifically at Nui Dat in the centre of the province has been criticised. Brigadier Jackson, who had been nominated to command 1 ATF, selected Nui Dat, and his decision was confirmed by Wilton when they flew over the area in the afternoon of 14 March. As Jackson recalled:

I remember flying over the Nui Dat with General Wilton and he looked down there and he said, 'Well one day there'll be an empire down there won't there?' And we had in other words pretty much agreed that that's where the Task Force would go. ${ }^{55}$

Jackson later explained that he selected Nui Dat because it was located between the enemy's Main Force bases and the areas of most dense civilian population. The base had to be capable not only of being held by a minimum force but also of providing for a small airfield, a task force maintenance area, and tactically located unit base areas with room to fight should the base come under heavy attack. There were three other factors. It had to be on ground which would be above water level during the wet season, which was due to begin one week after forward deployment began. It needed to be in relatively open ground and not too close to densely settled areas to enable maximum use of firepower rather than manpower for its defences. And it should be located close enough to the Vung Tau$\mathrm{Ba}$ Ria area to avoid diversion of forces for line of communication security duties or alternatively to allow maintenance by air. ${ }^{56}$ After the war Jackson still believed it was right to base 1 ATF at Nui Dat. ${ }^{57}$

Stretton thought the decision to base 1 ATF at Nui Dat was one of the 'cardinal blunders' made by the Australian commanders in Vietnam. ${ }^{58}$ The huge complex that was eventually developed had to be defended, thus reducing the numbers of troops that could be deployed on operations. If the troops had been located at Vung Tau fewer would have been needed to defend the base.

55 Ibid, $\mathrm{p} 50$

56 Brig OD Jackson, CGS Exercise 1971, Presentation Operation Hardihood - Deployment of 1 AF to Nui Dat.

57 Jackson interview, p 52.

58 Stretton, Soldier in a storm, p 213. 
Wilton's successor as CGS, Daly, thought 'with the advantage of hindsight' that 'it would have been a better proposition to develop Vung Tau as the Task Force base. In any future operation such as that, I think it would be most unwise to set up two permanent bases'. ${ }^{59}$ Further, the construction of the Nui Dat base required a large-scale engineering effort that was not appreciated at the time it was selected. As Brigadier Philip Greville, historian of the Royal Australian Engineers, has argued, there was no one 'accompanying General Sir John Wilton who understood engineering matters upon which the well-being of the forces would largely depend' ${ }^{60}$

Lieutenant General Sir Donald Dunstan, who was deputy commander of 1 ATF in 1968, COMAFV in 1971-72, and later CGS, thought the army made a:

fundamental mistake when we went into Phuoc Tuy in that we sat at Nui Dat in the manner in which we did. Nui Dat was always a pain in the neck; it was a large base, it became a relatively sophisticated base and it was always a heavy consumer of manpower. ${ }^{61}$

He thought if the base had been at Vung Tau there would have been a saving of personnel and the defensive task would have been far less demanding. Then, with the number of people the army had in Vietnam, it would have been possible to raise a force of four battalions. At any time, three battalions could have operated continually in Military Region 3 or Phuoc Tuy. To operate in Phuoc Tuy it was only necessary to provide fire support bases: 'I don't believe that you have to put the base there to separate the enemy from the civil population. ${ }^{62}$

Wilton rejected this argument. He wanted the troops based away from a populated area. Placing the base in the centre of the province posed a continuing threat to Viet Cong operations. And importantly, if the troops had been at Vung Tau the American high command might have wished to deploy them away from the province on the sort of deep operations that, from the beginning, he had wanted to avoid.

59 Army Historical Programme, interview with Lt Gen Sir Thomas Daly, 22 November 1974 and 4 June 1975, p 22, AWM 107.

60 PJ Greville, The Royal Australian Engineers 1945 to 1972: Paving the way, Corps Committee of the Royal Australian Engineers, Moorebank, NSW, 2002, p 721.

61 Army Historical Programme, interview with Maj Gen DB Dunstan, 4 October 1973. Copy of transcript given to the author by Dunstan at an interview on 23 December 1985.

62 Ibid. 
Major General Mackay, who took up his appointment as COMAFV in May 1966, thought the idea of basing 1 ATF at Vung Tau was 'ridiculous':

You can't go in as the big bold boys to sort this problem out and sit back ... at Vung Tau and then get in your damned trucks or helicopters every day and go for miles out in the bush and do something and come back [to] live in a villa or live by the seaside. ${ }^{63}$

But Mackay claimed the Nui Dat base he had in mind 'bore no relation to the hideous monster that developed later on'. He thought the task force maintenance area should have been at Vung Tau rather than Nui Dat.

When I went up there as QMG [quartermaster general] I almost blew a valve. I think there were about 290 fellows sitting on their backsides with a bloody great engineer's stores yard there with refrigerators and logs and timber and stuff ... I didn't envisage this enormous area of bitumen where you could bring in half the American air force. ${ }^{64}$

The historian Greg Lockhart has provided the most detailed criticism of the decision to locate 1 ATF at Nui Dat. ${ }^{65} \mathrm{He}$ points out that Australian Army counter-revolutionary warfare doctrine encouraged the establishment of a forward operational base, and indeed this concept had been practised during Exercise Sky High near Singleton in NSW in November 1963. ${ }^{66}$ Lockhart argues that Wilton and Jackson (and for that matter Mackay also) misunderstood the nature of the war in Vietnam in claiming that a base at Nui Dat would separate the enemy from the population in central and south-western Phuoc Tuy. Lockhart points out that many residents in Ba Ria and Long Dat, which the Nui Dat base was supposed to separate from the Viet Cong, supported or were actual members of the Viet Cong. Lockhart sees the decision as evidence of Wilton's 'barrier mentality'. He and successive 1 ATF commanders never 'understood the web of mutually supportive relations between the local semi-regular and regular guerrilla units and national PAVN [People's Army of Vietnam] main forces'. Lockhart argues that Wilton 'never fully comprehended' that the ground of tactical importance in Phuoc Tuy Province was in the south, in the Long Hai Hills, where substantial

63 Mackay interview, pp 17, 18. Mackay was QMG from 1968 to 1973.

64 Ibid.

65 Greg Lockhart, The minefield: An Australian tragedy in Vietnam, Allen \& Unwin, Sydney, 2007, ch 2 .

66 McNeill, To Long Tan, pp 18, 19. 
Viet Cong forces had been based for many years. ${ }^{67}$ That is, Wilton and the other Australian Army leaders not only failed to understand the nature of the war in Vietnam, but had no knowledge of the history of the Viet Cong in Phuoc Tuy Province.

There is, however, a contrary view. Ian McNeill, author of the official history, has shown that senior North Vietnamese and Viet Cong officers agreed that the location of 1 ATF at Nui Dat presented a great obstacle to their operations. ${ }^{68}$ Further, in discussing the Battle of Long Tan in August 1966, McNeill concluded:

The decision to place the task force at Nui Dat and the subsequent operations had been designed to separate the guerrillas from the people, a fundamental tenet of Australian counter-insurgency doctrine. These activities had apparently taken effect, forcing the enemy to confront the task force as Jackson had anticipated. ${ }^{69}$

Major General Bob Hay, who as a brigadier accompanied Wilton and Jackson on the reconnaissance to Phuoc Tuy in March 1966 (and was COMAFV in 1969-70), agreed that the Task Force should have been located at Nui Dat:

It was better to put this on the ground between the main centres of population and true jungle area, which were dominated by the VC and NVA [North Vietnamese Army] ... In the long term I think this proved to be a wise move, although it did mean a substantial base was, in fact, developed in Nui Dat, and this really was not, I am quite sure, the thought in $1966 .^{70}$

While Wilton and Jackson's decision to locate 1 ATF at Nui Dat can be understood in terms of creating a presence in the province, in retrospect perhaps there was another alternative. As Dunstan suggested, the Task Force could have been based at Vung Tau with a large fire support base located forward at Nui Dat, but still much smaller than the eventual 1 ATF complex. This is a variation on Mackay's idea. Later in the war,

67 Greg Lockhart, 'Extracts from The Minefield', The Vietnam Veteran Newsletter, September 2003, pp 18, 19.

68 McNeill, To Long Tan, p 200. For further criticism of the decision, see Ian McNeill and Ashley Ekins, On the offensive: The Australian Army in the Vietnam War, January 1967-June 1968, Allen \& Unwin, Sydney, 2003, pp 63-4.

69 McNeill, To Long Tan, p 366.

70 Army Historical Programme, interview with Maj Gen RA Hay, 22 November 1971, p 7, AWM 107. 
battalion fire support bases were established at Courtenay Hill and the Horseshoe for months on end. They had the desired effect of dominating the surrounding areas. $^{71}$

\section{Important decisions}

The decision to locate 1 ATF in Phuoc Tuy Province and specifically at Nui Dat reveals Wilton's determination not to place the lives of Australians at risk in more adventurous American operations. He also wanted to ensure that 1 ATF had the best possible opportunity to conduct operations according to Australian tactical doctrine. He had been reminded of the differences between Australian and American doctrine when, on the afternoon of 13 March 1966, he visited 1 RAR on Operation Silver City, deep in War Zone D, where the 173rd Brigade was engaged in destroying the headquarters of the Viet Cong 7th Military Region. Three days later three Viet Cong battalions attacked one of the US battalions and Australian gunners fired continuously for four hours to break up the Viet Cong assaults. $^{72}$

Wilton concluded his visit to Vietnam in the morning of 17 March, when he signed a Military Working Agreement with Westmoreland, who noted in his diary that the 'Australians are pleased to deal with us and there is apparently a mutual friendship between the officers of our two nations and a common outlook'. ${ }^{73}$ Wilton then headed home and on 23 March the Chiefs of Staff Committee endorsed the arrangements that he had made in Vietnam. ${ }^{74}$

Wilton's visit to Vietnam in March 1966 was the most important by any Australian military chief during the Vietnam War and, according to Malcolm Fraser, it was carried out 'brilliantly'. ${ }^{75}$ Lockhart and others would argue, however, that the decision to place 1 ATF at Nui Dat was flawed. Whatever the judgement on this issue, Wilton's decision established 1 ATF in Phuoc Tuy Province and set guidelines for its

71 For a description of 1 ATF fire bases see Bruce Picken, Fire support bases Vietnam: Australian and allied fire support base locations and main support units, Big Sky Publishing, Newport, NSW, 2012.

72 Bob Breen, First to fight: Australian diggers, N.Z. kiwis and U.S. paratroopers in Vietnam 196566, Allen \& Unwin, Sydney 1988, p 233.

73 Westmoreland Diary, 17 March 1966, US Army Center of Military History.

74 COSC Minute, 23 March 1966, CCOSC files, box 25, file 1910.

75 Interview, JM Fraser with author, 18 November 2002. 
employment that were to continue for the remainder of the war. These guidelines were a clear reflection of the Australian Government's policy of minimising the chances of excessive casualties. His visit also established the command arrangements. The decision to appoint the COMAFV, who reported to the Chiefs of Staff Committee through its chairman, set a precedent for appointing an Australian national commander with joint service responsibilities. This approach has persisted to the present day. As for the two-battalion task force, in December 1967 it was expanded to three battalions. Confrontation had ended in August 1966 and 9 RAR was raised in November 1967.

Before 1 ATF arrived at Nui Dat, Wilton had taken over from Scherger as Chairman of the Chiefs of Staff Committee, and when he was promoted to general in September 1968 he was the first Australian Army officer to reach this rank since General Sir Thomas Blamey was promoted in September 1941. In his new position, Wilton would continue to provide oversight of Australia's Vietnam commitment until he retired in November 1970. At that time 1 ATF, based at Nui Dat and reduced again to two battalions, was still operating in Phuoc Tuy Province. 
This text is taken from Vietnam Vanguard: The 5th Battalion's Approach to Counter-Insurgency, 1966, edited by Ron Boxall and Robert O'Neill, published 2020 by ANU Press, The Australian National University, Canberra, Australia.

doi.org/10.22459/VV.2019.02 